\title{
DYSKURS DIET ODCHUDZAJĄCYCH WE WSPÓŁCZESNEJ WLOSKIEJ PRASIE KOBIECEJ. ANALIZA JAKOŚCIOWA
}

\author{
JOANNA OZIMSKA
}

\begin{abstract}
The discourse of slimming diets in contemporary Italian women's press. Qualitative analysis. Based on a corpus of articles extracted from contemporary Italian female magazines (2021) Donna Moderna and Grazia, this paper examines the nature of discourse of slimming diet. It is shown that the discourse has changed compared to the study conducted on the material from 2005-2008. Altogether 29 monthly issues have been analyzed. Currently emerging corpus does not contain many persuasive techniques related to emotions (Aristotle's pathos), the credibility of provided advice is enhanced mostly by arguments from authority (ethos). The innovation thus lies in the references to currently important societal topics, such as ecology (a manifestation of linguistic fashion). The research based on a rhetorical tools and analysis of press discourse shows that the topic of weight loss is treated nowadays with greater awareness and is being transferred to the pages of the men's press, in women's magazines its place is taken by e.g., cosmetic-surgical, or ecologic discourse. The conclusions from own research have been preceded by a review of theoretical issues in the field of a modern concept of a slimming diet, myth of beauty, development of the press in Italy, the role of cuisine and food in the Italian women's press.
\end{abstract}

Key words: diet, Italian female magazines, persuasion, body, discourse of diet

\section{Pojęcie diety i dyskursu}

Rozważania o dyskursie diet odchudzających w prasie kobiecej warto rozpocząc od przejrzenia haseł słownikowych i definicji słów kluczowych dla niniejszego badania.

Wielki Słownik Języka Polskiego dzieli leksem dieta ${ }^{1}$ na cztery podkategorie. Pierwszą $^{2} \mathrm{z}$ nich jest dieta odchudzająca, definiowana jako „sposób odżywiania się

\footnotetext{
${ }^{1}$ https://wsjp.pl/do_druku.php?id_hasla=7949\&id_znaczenia=0 (dostęp: 11.04.2021).
} 
odbiegający pod względem ilości i rodzaju spożywanych pokarmów od powszechnie przyjętego". Jednocześnie dowiadujemy się wyraz pochodzi z greki i łaciny, gdzie

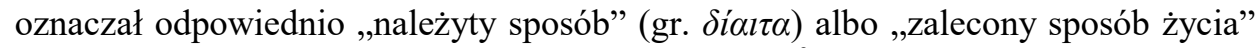
(łac. diaeta). Słownik zawiera także hasło dieta cud $^{3}$, które określa mianem żartobliwego i defniuje jako „dieta, która ma zapewnić komuś szybką i dużą utratę wagi”. Włoski słownik medyczny ${ }^{4}$ zwraca uwagę na dwa aspekty tego terminu: wymieniony na pierwszym miejscu, utożsamiany z szerszym postrzeganiem zjawiska, ogół składników odżywczych, spożywanych przez ludzi w celu zaspokojenia potrzeb pokarmowych, rozumiany jako styl życia (np. dieta śródziemnomorska), oraz, w węższym znaczeniu, ale częściej spotykanym, mianowicie ograniczenia w spożywaniu produktów, zalecone przez lekarza albo narzucone sobie przez człowieka spontanicznie w celu osiągnięcia poprawy zdrowia poprzez eliminację lub wdrożenie wybranych grup produktów spożywczych. Hasło uwzględnia również aspekt etyczny diety, np. wegetariańskiej.

$\mathrm{Z}$ pojęciem diety wiąże się także termin reżim, definiowany przez WSJP jako „sposób postępowania”, np. dietetyczny.

$\mathrm{W}$ tytule artykułu pojawia się również pojęcie dyskursu. To termin wieloznaczny, na który powołuje się wiele dyscyplin badawczych ${ }^{5}$. W moich rozważaniach będę rozumieć go jako „zdarzenie komunikacyjne - jednostkowe, krótkie lub długotrwałe użycie języka przez człowieka, który chce przekazać określone myśli i przekonania i/lub wpłynąć na słuchaczy" (Lisowska-Magdziarz 2006: 13). Jest to zatem nieprzypadkowe użycie języka do komunikowania w sytuacjach społecznych.

Wśród celów, jakie stawia sobie analiza dyskursów obecnych w mediach, można wymienić m.in. (a) odkrywanie i opisywanie ich perswazyjnego wymiaru oraz badanie środków używanych w tych dyskursach do wywierania wpływu na ludzi; (b) odsłanianie relacji władzy ${ }^{6}$ wpisanych w dyskurs; (c) denaturalizację dyskursów czyli zakwestionowanie zawartych w nich wizji i interpretacji świata, prezentowanych jako oczywiste i zdroworozsądkowe, co otwiera drogę do samodzielnego, krytycznego odbioru tekstów prasowych.

\footnotetext{
${ }^{2}$ Drugie znaczenie to jadłospis, czyli zestaw pokarmów jadanych przez kogoś, trzecie - dieta dojazdowa, hotelowa, pobytowa, a zatem przysługujące w podróży specyficzne wynagrodzenie kosztów wyżywienia i noclegu, czwarte dotyczy diety poselskiej, czyli uposażenia parlamentarzystów.

${ }^{3} \mathrm{https}: / /$ wsjp.pl/do_druku.php?id_hasla=44173\&id_znaczenia=4634574 (dostęp: 11.04.2021).

${ }^{4} \mathrm{https}: / /$ www.treccani.it/enciclopedia/dieta_\%28Dizionario-di-Medicina\%29/ (dostęp: 11.04.2021).

${ }^{5}$ M.in. językoznawstwo, psychologia, literaturoznawstwo, socjologia, antropologia, nauki o kulturze i religii, nauki polityczne.

${ }^{6}$ Władza rozumiana jako podmioty, niekoniecznie polityczne, które dążą do umocnienia swojej pozycji w hierarchii społeczno-gospodarczej i do narzucenia widzom/czytelnikom własnej wersji porządku społecznego, hierarchii wartości i sposobu interpretacji ważnych wydarzeń i zjawisk (por. LisowskaMagdziarz 2006: 19).
} 


\section{Wspólczesna koncepcja diety odchudzającej}

Socjolog Bryan S. Turner w artykule zatytułowanym "The discourse of diet" (1982: 25-27) dużo miejsca poświęcił szkockiemu lekarzowi, George’owi Cheyne'owi, którego można uznać za prekursora diet odchudzających w formie, jaką znamy współcześnie ${ }^{7}$. Cheyne (1671-1743) praktykował jako lekarz w Londynie i Bath, stosując dietę jako podstawowe remedium w przypadku przygnębienia. Do grona jego przyjaciół i pacjentów zaliczani byli m.in. filozof David Hume, pisarz Samuel Richardson, pisarz i leksykograf Samuel J. Johnson, teolog John Wesley, poeta Alexander Pope. Publikacje Cheyne'a zachwalające zdrowotne walory diet były efektem jego osobistych doświadczeń - borykając się z otyłością i angielską melancholią, przetestował na sobie dietę opartą na spożywaniu mleka i warzyw, co rzekomo zapewniło mu spokojną i długą starość. Zainspirowany mechanistycznym modelem ciała Kartezjusza, Cheyne uznał, że kondycja zdrowotna człowieka uzależniona jest od dostarczania organizmowi odpowiedniej pod względem jakościowym i ilościowym żywności. Wśród innych źródeł jego inspiracji należy wymienić „Trattato della vita sobria” (1558), którego autor, Alvise Cornaro, również wypróbował na sobie działanie reżimu dietetycznego, aby pokonać problemy zdrowotne. Z czasem Cheyne dostrzegł, że bogatsze klasy Brytyjczyków podupadają na zdrowiu taką grupę stanowili jego pacjenci - a przyczynił się do tego postęp cywilizacyjny: rozwój ekonomiczny i związany z nim dostęp do nowych rynków produktów żywnościowych negatywnie wpłynął na społeczny metabolizm. Dokonujące się zmiany w nawykach żywieniowych ${ }^{8}$ oraz pojawiające się mody kulinarne były odejściem od natury i musiały prędzej czy później odbić się na kondycji zdrowotnej poszczególnych warstw społeczeństwa, w szczególności intelektualistów i arystokracji, prowadzących siedzący tryb życia. Sama dieta, oparta na spożywaniu warzyw, owoców, zbóż, mleka nie była oryginalnym pomysłem Cheyne’a, jej źródeł należy upatrywać w starożytnej medycynie greckiej ${ }^{9}$. To, co stanowiło wkład Cheyne'a to stworzenie

${ }^{7}$ Giddens (2012: 145) wskazuje moment narodzin „diet”, w wąskim znaczeniu tego pojęcia, na początek lat dwudziestych XX wieku, kiedy zanikło kojarzenie korpulentnej sylwetki z zamożnością. „Bycie na diecie w węższym znaczeniu tego wyrażenia jest szczególnym przypadkiem ogólniejszego zjawiska, polegającego na poddawaniu ciała reżimom dietetycznym w celu osiągnięcia jakiegoś efektu tożsamościowego".

${ }^{8} \mathrm{~W}$ zasługujący na zainteresowanie sposób zmiany nawyków żywieniowych Europejczyków, w tym szczególnie Brytyjczyków, opisał w eseju o cywilizowaniu apetytu Stephen Mennell (1987: 373-403).

${ }^{9} \mathrm{~W}$ starożytnej Grecji termin ,dieta” odnosił się nie tylko do jedzenia, ale do stylu życia (Mazzini 1999: 141). Dietetyka stanowiła jedną z trzech dziedzin medycyny, obok chirurgii i farmakologii. Do klasycznych metod leczenia zaliczymy reżimy dietetyczne, gimnastykę, uprawianie sportów, kąpiele, sen, aktywność seksualną, wymioty oraz stosowanie środków przeczyszczających (Mazzini 1999: 142). Dietetyka była formą leczenia zarezerwowaną dla bogatych klas społecznych, grupy uboższe były zmu- 
klasyfikacji obrazującej jak poszczególne kategorie wiekowe powinny różnicować spożycie wybranych produktów w oparciu o deficyt kaloryczny ${ }^{10}$. W celu zachowania zdrowia Cheyne rekomendował odpowiednio lekką dietę, jazdę konną, regularny sen oraz wymioty (sic!). Spostrzeżenia i zalecenia Cheyne'a dotyczyły elit społecznych, ale dzięki działalności wspomnianego wcześniej duchownego Johna Wesleya, zaproponowany model zarządzania dietą dotarł także do klasy średniej, zyskując wymiar religijny ${ }^{11}$, którego podejście Cheyne'a było pozbawione.

Kolejne, warte odnotowania, zmiany w społecznym stosunku do kontrolowania wagi obywateli wiążą się z nastaniem kapitalizmu: schorowana siła robocza narażała na ryzyko kapitalistyczną wydajność pracy (Turner 1982: 30-32), przy czym należy pamiętać, że początkowo robotnicy cierpieli raczej z powodu niedoborów żywności ${ }^{12}$, a zatem otyłość im nie zagrażała. Światowe wojny i związane z nimi powołania na front obnażyły coraz gorszy stan zdrowia męskiej części klasy pracującej. Pozorna troska o los obywateli, a w szczególności ich ciał, przeniosła się na grunt szkół, przyjmując formę prewencji. Turner (1982: 31) przypomina ważną koncepcję Foucaulta - w ten sposób, przy wykorzystaniu systemu szkolnictwa, opieki medycznej i pracy, realizowało się społeczne dyscyplinowanie ludzkich ciał ${ }^{13}$.

szone korzystać z farmakologii i chirurgii, co często kończyło się śmiercią. Świat antyczny pozostawił po sobie wiele pisemnych świadectw dedykowanych relacji między dietą a zdrowiem, do których zaliczamy m.in. twórczość Hipokratesa (De diaeta, De diaeta in acutis, De salubri diaeta), Galena, Orubazjusza, Anthimusa (De observatione ciborum), Pedaniosa Dioskurydesa.

${ }^{10}$ Turner (1982: 31) przypomina, że naukowe zainteresowanie mierzeniem relacji między ilością spożywanych kalorii a zapotrzebowaniem organizmu wzięło początek z obserwacji więźniów i żołnierzy. Chodziło o ustalenie minimalnej ilości kalorii, których spożycie zapewniałoby maksimum wydajności fizycznej.

${ }^{11}$ Inny wymiar religijności, o którym warto wspomnieć przy okazji, miało zaobserwowane w średniowieczu, a opisane przez badaczy w siedemnastym i osiemnastym wieku, zjawisko anorexia mirabilis, określane jako cudowna utrata apetytu (Giddens 2012: 144). Chodzi o praktyki długotrwałego wyrzekania się pokarmu przez średniowieczne kobiety w celu osiągnięcia świętości i zbawienia.

${ }^{12}$ „Aż do obecnego stulecia większość ludzkiej populacji żyła w kulturze strukturalnego niedostatku żywności, której zasoby były dystrybuowane w ramach systemu reguł zapewniających przetrwanie grup, uznawanych za szczególnie ważne dla przetrwania danej społeczności. W drugiej połowie XX w. sytuacja ta zaczęła się szybko zmieniać, dzięki postępowi w rolnictwie i zmianom w organizacji państwa" (Płonka-Syroka 2018: 7).

${ }^{13}$ „Tematyka ciała w najnowszej teorii socjologicznej szczególnie kojarzy się z nazwiskiem Foucaulta. Analizy Foucaulta dotyczą relacji ciała i mechanizmów sprawowania władzy, a w szczególności pojawienia się w epoce nowoczesnej «władzy dyscyplinującej». Ciało staje w centrum uwagi nowoczesnej władzy, która w przeciwieństwie do władzy przednowoczesnej, nie dąży do «naznaczenia» go, ale w zamian poddaje wewnętrznej dyscyplinie i samokontroli. Przedstawione przez Foucaulta (1998) mechanizmy dyscypliny prowadzą do ukształtowania posłusznych ciał" (Giddens 2012: 85). W literaturze przedmiotu znajdziemy też odmienne opinie, nazywające zjawiska ostatnich dekad społeczną rehabilitacją ciała: „ciało zostało nie tylko zrehabilitowane i przywrócone do łask, ale wręcz wystawione na pokaz" (Prost i Vincent 2006: 118-119). 


\section{Kult ciała, mit piękna, walka ze starością}

W XX wieku status ciała zmienił się (Prost i Vincent 2006: 109-113). Chociaż w przypadku ciał robotników nadal chodziło najbardziej o fizyczną wytrzymałość i zdolność do wysiłku, powoli zaczęto propagować zasady czystości i higieny. Troska o wygląd zewnętrzny zaczęła dotyczyć w coraz większej mierze ciał kobiet. Ubrania odsłaniały coraz więcej, w prasie pojawiły się zachęty do aktywności fizycznej podejmowanej w celu innym niż praca ${ }^{14}$, jak również sugestie, by przestrzegać lekkostrawnej diety. Na łamach czasopism zaczęto propagować kult atrakcyjności fizycznej, który przetrwał a nawet zintensyfikował się w czasach współczesnych.

Określony wygląd ciała i sposób bycia wyraźnie nabierają szczególnego znaczenia z nastaniem nowoczesności. W kulturach przednowoczesnych wygląd był z reguły znormalizowany ze względu na tradycyjne nakazy. Na przykład ozdabianie i malowanie twarzy zawsze w jakimś stopniu miało wyróżniać jednostkę, ale zakres, w którym zastosowanie tych środków w takim celu było możliwe lub pożądane, był zwykle mocno ograniczony. [...] W kontekście wcześniej omawianych kwestii wygląd zewnętrzny staje się centralnym elementem refleksyjnego projektu ,ja”. (Giddens 2012: 138-139)

Jednym z aktywnych uczestników tego procesu zmian społecznych byli producenci produktów kosmetycznych i odzieży (Prost i Vincent 2006: 114) ${ }^{15}$. Do upowszechniania nowych wzorów w społeczeństwie przyczyniły się również prasa, radio $\mathrm{i}$ telewizja ${ }^{16}$. Działając w ten sposób doprowadzono do istotnych zmian w codziennej pielęgnacji: $\mathrm{w}$ latach 1966-1967 kobiety we Francji deklarowały, że średnio poświęcają urodzie godzinę, mężczyźni - niewiele mniej (Prost i Vincent 2006: 115).

${ }^{14}$ „Gimnastykę zalecały pisma kobiece jeszcze przed II wojną światową” (Prost i Vincent 2006: 116).

15 „Zanim uda się sprzedać szampon czy pastę do zębów, trzeba najpierw rozpropagować ideę mycia włosów i zębów, głównie za pomocą reklamy, ukazującej np. fryzurę i uśmiech gwiazdy filmowej. Nie sposób również sprzedać kremu do opalania, dopóki powrót z wakacji z piękną opalenizną nie stanie się wymogiem społecznym. W ten sposób handel znacznie bardziej niż higieniści przyczynił się do upowszechnienia nowych zwyczajów dotyczących pielęgnacji ciała".

${ }^{16}$ „Globalny zasięg i coraz silniejsze oddziaływanie nowoczesnych mediów na zachowania i świadomość społeczną, zmieniają dziś znaczenie, wymiar i rolę środków masowego przekazu. Cierpiący na brak czasu młodzi ludzie, wygodni czytelnicy (widzowie) i zdeterminowani reklamodawcy zmuszają coraz częściej redaktorów i wydawców ambitnych mediów do zaniżania poziomu prezentowanych treści. Spełnianie oczekiwań zachowawczej i leniwej intelektualnie większości sprawia, że zamiast ukazywania nowych kierunków rozwoju i kreowania świata aspiracyjnego, media stanowią dziś swoistą formę nowoczesnej AGORY, punkt odniesienia dla zachowań i orientacji światopoglądowych, stając się wyznacznikiem obowiązujących kanonów piękna, norm kulturowych czy wartości” (Kędzierska 2015: 141). Problem w tym, że w przypadku stosunku do ludzkiego ciała, a w szczególności do ciała kobiecego, media proponują wzorce zachowań i modele do naśladowania, które odbiegają znacząco od możliwości dostosowania się przez typowe czytelniczki czy słuchaczki. 
Błatej (2005: 58-59) nazywa proces współcześnie dokonujący się na ciałach kobiet „negatywną kulturystyką”, gdyż pożądany z punktu widzenia społeczeństwa kształt ciała osiąga się poprzez jego niwelowanie („tyrania szczupłego ciała”). Ponadto - zauważa - ciało kobiet podlega ,wizualnemu dzieleniu na strefy konsumpcji” a zatem fragmentyzacji.

Aby w pełni nakreślić rolę ciała $\mathrm{w}$ świecie posttradycyjnym, nie można pominąć kwestii wieku. „Norma społeczna wymaga, by wyglądać młodo, a osobowość do tego stopnia identyfikuje się z ciałem, że pozostać sobą znaczy niemal to samo, co pozostać młodym" (Prost i Vincent 2006: 123).

Podsumowując ten fragment rozważań, warto przytoczyć spostrzeżenia poczynione przez Baumana:

Ciało ponowoczesności to, w przeciwieństwie do ciała nowoczesności, ukierunkowanego celowo i zadaniowo, sprawne, zdrowe, utrzymane w dobrej formie ciało będące gotowe na odbiór doznań i przeżywanie przyjemności: seksualnej, kulinarnej, estetycznej czy płynącej z uprawiania sportu. Ciało niebędące w formie oznacza słabość, niezdolność do konsumowania wrażeń, apatię (Puto 2014: 104).

Mit urody uderza głownie w kobiety, pozbawiając je przyjemności z feministycznych zdobyczy (Wolf 2014: 25).

Mit zawłaszcza - powoli, niezauważalnie, poza naszą świadomością tego, jakie siły stoją za tą erozją - przestrzeń, którą zdobyłyśmy w wyniku długich, ciężkich i honorowych walk. Mit urody jest bardziej podstępny niż jakakolwiek mistyka kobiecości. [...] W miejscu, w którym więzi się nas dziś, nie ma żadnych drzwi, którymi można by trzasnąc. Współczesne spustoszenia czynione przez ideologię urody niszczą nas fizycznie i wyczerpują psychicznie. Jeśli mamy się podźwignąć spod balastu nałożonego po raz kolejny na kobiecość, nie potrzebujemy głosowania, wywierania politycznego nacisku ani transparentów, przede wszystkim potrzebujemy nowej perspektywy (Wolf 2014: 38).

Odpowiedź na pytanie, jaką perspektywę stawia przed kolejnymi grupami czytelniczek współczesna włoska prasa odnajdziemy, przynajmniej częściowo, w drugiej części niniejszego opracowania.

\section{Rozwój prasy we Włoszech. Włoska prasa kobieca}

Początki periodyków na obszarze Półwyspu Apenińskiego można datować na rok 1636 i 1639, odpowiednio we Florencji i w Genui (Karczewska 2018: 132). Ich tematyka dotyczyła głównie wojen i traktatów, były dystrybuowane z częstotliwością co osiem dni i nie miały wiele wspólnego ze współczesną prasą, stanowiły raczej zbiór luźnych kartek, bez nagłówków.

Pierwszy ukazujący się w miarę regularnie dziennik opublikowano w Genui w 1642 roku. Opóźnienie w stosunku do innych europejskich wydawnictw wynikało 
z cenzury, zarówno kościelnej, jak i narzuconej przez ówczesną władzę, skutecznie hamującej rozwój prasy.

Rozkwit tego rodzaju działalności zaobserwowano w drugiej połowie XVIII wieku, a jego pierwszym znakiem był periodyk Il Caffè (Karczewska 2012: 133). Wielkiej rewolucji francuskiej zawdzięczamy, natomiast, zmianę poruszanych tematów i początek krytyki politycznych dokonań urzędujących przywódców. Kontrola treści powróciła wraz z nastaniem ery napoleońskiej (Karczewska 2012: 133). Reżim Bonapartego poszedł o krok dalej, ustanawiając własne tytuły, na łamach których cesarz był porównywany do Aleksandra Wielkiego i Karola I Wielkiego.

Po roku 1815, pomimo cenzury, pojawiło się wiele nowych wydawnictw literackich i poświęconych kulturze, na łamach których udawało się przemycić wątki polityczne. Do najważniejszych zaliczymy Il Conciliatore ${ }^{17} i_{\text {L'Antologia }}{ }^{18}$.

Zjednoczenie Włoch przyczyniło się do rozkwitu prasy codziennej. Niektóre tytuły, powołane do istnienia w tym okresie, nadal funkcjonują: Corriere della Sera (1876), La Stampa (1867), La Nazione (1859). Początki działalności były trudne z uwagi na wysokie koszty funkcjonowania redakcji oraz wysoki odsetek analfabetyzmu w pozjednoczeniowym społeczeństwie (Karczewska 2012: 134). Trudny dla rozwoju wydawnictw okazał się również wiek XX, ze względu na dwie wojny światowe i faszystowską cenzurę.

Po roku 1945 we Włoszech zaczęły ukazywać się zitalianizowane edycje czasopism zagranicznych, np. Cosmopolitan. W XX wieku powołano do życia tygodniki społeczno-polityczne L'Espresso (1955), Panorama (1939) oraz prasę sportową: Gazzetta dello sport (1986) i Corriere dello Sport (1924). To również czas intensywnego rozwoju czasopism adresowanych do dziewcząt i kobiet.

Karczewska (2012: 134-135), powołując się na dane zaczerpnięte z jednego $\mathrm{z}$ rozdziałów, zawartego w Storia della stampa italiana autorstwa Laury Lilli, przypomina, że udział czasopism dla kobiet we włoskim rynku wydawniczym jest istotny, chodzi o 45 tytułów, w przypadku których liczy się nie tylko ilość, ale i nakład. W 1976 roku ogółem ukazało się 2,6 mln kopii miesięczników i 6,9 mln egzemplarzy tygodników dla pań, przy czym włoska autorka szacuje, że zasięg czytelnictwa był dużo większy. Dzielenie się prasą z bliskimi oraz przeglądanie periodyków podczas wizyt w salonach fryzjerskich i kosmetycznych może oznaczać blisko $30 \mathrm{mln}$ czytelniczek i czytelników.

Za pierwszy skierowany do czytelniczek tytuł publikowany w języku włoskim można uznać wydawany we Florencji miesięcznik Il Giornale delle dame (17811823). Pięć lat później w Wenecji ukazał się i utrzymał na rynku wydawniczym

\footnotetext{
${ }^{17}$ Tytuł przestał się ukazywać w październiku 1819. https://www.treccani.it/enciclopedia/ilconciliatore (dostęp: 26.06.2021).

${ }^{18}$ Powołany do życia w styczniu 1821 roku, ukazywał się do 1833 . Począwszy od 1866 publikowany pod zmodyfikowanym tytułem Nuova Antologia. Wśród współpracowników znajdował się, m.in., Giacomo Leopardi. https://www.treccani.it/enciclopedia/antologia (dostęp: 26.06.2021).
} 
przez rok miesięcznik La donna galante ed erudita - Giornale dedicato al bel sesso. W 1804 roku w Mediolanie doszło do publikacji pierwszego numeru Corriere delle dame. Tygodnik wyróżniał się podejmowaniem tematyki politycznej, popierał emancypację kobiet $\mathrm{i}$ ich zaangażowanie w życie polityczno-społeczne. Przetrwał do 1875 roku. Inne tytuły o historycznym znaczeniu to, m.in.: La Moda (1820), Il Giornale della donna (1918-1942), Rassegna femminile italiana (1925-1930), Grazia (1938-), Donna Moderna (1988-), Amica (1962-), Gioia (1937-2018), IO Donna (1996-), D-la Repubblica delle donne (1996-) oraz włoskie wersje zagranicznych formatów Elle (1987-), Vanity Fair (1990-1991, 2003-), Marie-Claire (1987-).

\section{Miejsce kuchni i żywności we włoskiej prasie kobiecej}

Zanim przedstawię metodologię badawczą i zakres analizowanego materiału, krótko chciałabym zatrzymać się na zagadnieniu mocno osadzonym we włoskiej kulturze, a mianowicie na kuchni i jedzeniu. Włosi od zawsze dużo miejsca poświęcają rytuałom przyrządzania posiłków i biesiadowaniu ${ }^{19}$. Mają swoje lokalne tradycje, receptury ${ }^{20}$ przekazywane $\mathrm{z}$ dziada pradziada (albo raczej z włoskiej nonny na mamme), korzystają z najwyższej jakości składników, w trosce o to, co jemy i jak jemy, stworzyli nawet ruch Slow Food ${ }^{21}$. Nie dziwi zatem fakt, że niemal każdy periodyk publikowany we Włoszech, bez względu na grupę docelową i tematykę, zawiera działy poświęcone kuchni albo przynajmniej porusza od czasu do czasu zagadnienia z nią związane.

W przypadku prasy kobiecej zaobserwowano obecność czterech głównych typologii tekstów powiązanych z tą tematyką. Pierwszą i najbardziej liczną grupę stano-

${ }^{19}$ Wspólne spożywanie posiłków było jednym z elementów odróżniających cywilizowanego człowieka od świata zwierząt i barbarzyńców według systemu wartości starożytnych Greków i Rzymian (Montanari 1999: 69-71). Jedzenie nie było postrzeganie jako zwykły akt zaspokajania potrzeb, stanowiło wydarzenie o randze społecznej i integracyjno-komunikacyjnej. Siedzenie przy wspólnym stole podczas bankietu świadczyło o przynależności do wspólnoty i jednoczyło ją, jednocześnie brak zaproszenia do biesiadowania oznaczał wykluczenie. Zupełnie normalnym zjawiskiem było różnicowanie spożywanego przez biesiadników, biorących udział w tym samym wydarzeniu, pożywienia - jedzenie serwowano w zależności od statusu uczestnika, również zajmowane miejsce przy stole było od niego uzależnione. Liczne teksty potwierdzają istnienie rytualnych bankietów już w trzecim tysiącleciu przed naszą erą w Sumerze (Flandrin 1999: 19).

${ }^{20}$ Najstarsze znane przepisy kulinarne datowane są na drugie tysiąclecie przed naszą erą i pochodzą z obszaru Mezopotamii (Flandrin 1999: 16). Nie oznacza to jednak, że mieszkańcy tego obszaru wynaleźli sztukę kulinarną. Starożytni Egipcjanie nie czuli potrzeby spisywania przepisów, mimo to dysponowali zaawansowanymi technikami gotowania już w czwartym tysiącleciu przed nasza erą (Flandrin 1999: 17).

${ }^{21}$ Por. Wiśniewska (2012). 
wią tradycyjne przepisy kulinarne. Druga kategoria to wywiady z ludźmi ze świata gastronomii: restauratorami, mniej lub bardziej sławnymi szefami kuchni, rolnikami powracającymi do dawnych metod upraw ziemi itp. Trzecia kategoria to wszechobecne reklamy produktów żywnościowych. Ostatnią grupę stanowi dyskurs diet, któremu warto poświęcić uwagę, by dostrzec jego charakterystyczne cechy, jak również przemiany jakim podlega $\mathrm{w}$ miarę upływu czasu. Dyskurs diet różni się ponadto w zależności od kultury, w której występuje. Innych środków perswazji używa się w tekstach adresowanych do Polek, inaczej wygląda sytuacja mieszkanek Półwyspu Apenińskiego i formułowany do nich przekaz. Dyskurs diet odchudzających rozgościł się również w prasie męskiej i w takim samym stopniu zasługuje na zainteresowanie badaczy.

\section{Zakres badania i metodologia}

Dyskurs diet odchudzających od dawna interesuje badaczy z całego świata, działających w ramach dziedzin takich jak nauki medyczne ${ }^{22}$, społeczne ${ }^{23}$ (socjologia, psychologia), rolnicze (technologia żywności i żywienia), humanistyczne (historia, filozofia), funkcjonująca niejako na styku nauk antropologia, przy czym niewiele analiz ma charakter językoznawczy. Niniejszy artykuł stawia sobie za cel wypełnienie, przynajmniej częściowe, tej luki pod względem jakościowym i komparatywnym.

Dyskurs diet obecny w prasie kobiecej jest głęboko powiązany z płcią kulturową $^{24}, \mathrm{z}$ obowiązującym w poszczególnych epokach i kulturach kanonem piękna a zatem wpisuje się w nurt badań genderowych.

Analizie zostanie poddanych 16 numerów ukazującego się raz w tygodniu włoskiego czasopisma dla kobiet Donna Moderna i 11 egzemplarzy włoskiej edycji tygodnika Grazia, opublikowanych w okresie 1 stycznia - 15 czerwca 2021. To periodyki, które można zaliczyć do grupy poradnikowo-rozrywkowych ${ }^{25}$, czasopism wielotematycznych ze średniej półki. Jednocześnie są to tytuły od początku związane nierozerwalnie z Italią a nie dostosowane do włoskich realiów zagraniczne formaty, co było nie bez znaczenia dla wyboru materiału badawczego.

${ }^{22}$ Por. Rodgers (2016).

${ }^{23}$ Por. Rebrovick (2015).

${ }^{24}$ „Wiemy znacznie więcej na temat standardów kobiecego piękna w innych kulturach niż o standardach piękna męskiego - po części dlatego, że to mężczyźni tworzyli te standardy" (Kimmel 2015: 446-447).

${ }^{25}$ Zawartość poszczególnych rubryk zmienia się w miarę upływu czasu, dlatego oprócz typowych porad, znajdziemy w nich sekcje shoppingowe (przykłady produktów z wskazaniem cen i adresów sklepów), ale i elementy charakterystyczne dla prasy people \& style (np. fotorelacje z ważnych imprez kulturalnych albo towarzyskich), por. Surendra (2019: 28-30). Można te tytuły określić mianem pism life style, gdyż ich rolą jest kształtowanie określonych postaw, proponowanie systemów wartości, stylu życia osobistego lub zawodowego. 
Do analizy zastosowano narzędzia retoryczne zaproponowane przez Arystotelesa. Ponieważ dyskurs diet odchudzających przeważnie nie stanowi bardzo rozbudowanej logicznie argumentacji - pojawia się w prasie kobiecej niejako mimochodem - uwaga będzie skoncentrowana na poszukiwaniu odniesień do arystotelesowskiego trójkąta: logos, ethos, pathos. Weryfikacji będzie podlegać również lista klasycznych toposów. Ponadto posłużę się instrumentami, które podsuwa analiza dyskursu. Postaram się odpowiedzieć na następujące pytania: (1) kim jest nadawca tekstów, czy da się go zidentyfikować, (2) jak zbudowany jest dyskurs, (3) do kogo jest adresowany, (4) w jakiej sytuacji społecznej jest realizowany i (5) jak może zostać zrozumiany i odebrany przez odbiorców.

Wyniki zostaną zestawione m.in. z obserwacjami, poczynionymi na porównywalnym materiale włoskojęzycznym $\mathrm{z}$ lat 2005-2008 (Ozimska 2019: 276-302) a zatem na tyle odległym, by wskazać pewne ogólne tendencje.

\section{Analiza korpusu}

\subsection{Wątki kulinarne ogółem}

W celu dowiedzenia, że wątki związane z żywnością w znacznej ilości i różnorodnej formie pojawiają się na łamach włoskiej prasy kobiecej, zostaną przytoczone dane, zaczerpnięte $\mathrm{z}$ analizowanego materiału - poniżej dla przykładu szczegółowe informacje dotyczące egzemplarza tygodnika Donna Moderna z 11 lutego 2021 (nr 9, s. 124), a w następnej części pracy zestawienie tabelaryczne dotyczące całego korpusu.

W pierwszym analizowanym numerze czasopisma zaobserwowano obecność pięciu przekazów reklamowych (wino Tavernello, pistacje amerykańskie, makaron Divella, narzędzia kuchenne, stanowiące dodatek do kolejnych edycji czasopisma, herbatki Pompadour). Dodatkowo jedna z pozostałych reklam zachwalała właściwości preparatu wpływającego na poprawę metabolizmu (Metarecod).

W numerze 9/2021 znalazł się ponadto trzystronicowy wywiad Anny Magli z piekarzem, który pracuje w oparciu o stare, zapomniane receptury ("Benvenuti nel nostro forno ZEN"26, s. 28-30).

Najliczniejszą grupę stanowiły porady z jedzeniem „w tle”. Dwie sugerowały wykorzystanie sytuacji wspólnego spożywania posiłków do osiągnięcia innych celów ("Cerchi lavoro? Prendi un aperitivo ${ }^{27 ”, ~ s . ~ 10 ; ~ " T i ~ v a ~ u n ~ c a f f e ̀ ? ~}{ }^{28 ”, ~ s . ~ 97) . ~ P o n a d-~}$

${ }^{26}$ „Witajcie w naszym piecu ZEN”, tł. JO. Jeśli nie wskazano inaczej, wszystkie tłumaczenia z języka włoskiego na język polski pochodzą od autorki.

${ }^{27}$ „Szukasz pracy? Wybierz się na drinka”.

${ }^{28}$ „Masz ochotę na kawę?”. 
to w numerze zamieszczono dwustronicowy tekst Manueli Soressi "L'arte di combinare le spezie ${ }^{29, " ~(s . ~ 106-107) ~ o r a z ~ t r z y ~ s t r o n y ~ p r z e p i s o ́ w ~ k u l i n a r n y c h ~(s . ~ 109-111) . ~}$

W poddanym badaniu numerze wykorzystano dużo przestrzeni na prezentację zagadnień około żywieniowych, klasyczny dyskurs diet w tej sytuacji mógłby zostać odebrany jako nadmiarowy.

Poniższe zestawienie zawiera dane na temat reklam ${ }^{30}$ powiązanych z żywnością, opublikowanych w 13 analizowanych numerach tygodnika Grazia i 16 numerach Donna Moderna.

Tab. 1. Reklamy żywności i artykułów z nią powiązanych

\begin{tabular}{|c|c|}
\hline 1 & wino Tavernello, $\mathrm{DM}^{31} 9 / 21,11 / 21,12 / 21,13 / 21,15 / 21,17 / 21,19 / 21$ \\
\hline 2 & pistacje amerykańskie, DM 9/21, 11/21, 16/21, 18/21, 21/21 \\
\hline 3 & makaron Divella, DM 9/21 \\
\hline 4 & narzędzia kuchenne, DM 9/21, 11/21, G 10/21 \\
\hline 5 & herbatki Pompadour, DM 9/21, 15/21 \\
\hline 6 & jabłka Pink Lady, DM 11/21, G 5/21 \\
\hline 7 & ser Parmigiano Reggiano, DM 11/21, G 11/21, 13/21 \\
\hline 8 & szafran 3 Cuochi, DM 11/21, 13/21, 15/21 \\
\hline 9 & herbatniki Divella, DM 11/21 \\
\hline 10 & $\begin{array}{l}\text { akcesoria kuchenne Tescoma, DM 12/21, 13/21, 16/21, 18/21, G 12/21, 13/21, 14_15/21, 17/21, } \\
\text { G } 18 \_19 / 21\end{array}$ \\
\hline 11 & alkohole Ruffino, DM 15/21, 16/21, G 12/21, 13/21, 14_15/21 \\
\hline 12 & herbatki Foodness, DM 15/21 \\
\hline 13 & makaron Le stagioni d'Italia, DM 15/21 \\
\hline 14 & produkty bez laktozy Candia, DM 15/21, 24/21 \\
\hline 15 & mozzarella Brimi, DM 18/21, 26/21 \\
\hline 16 & szwajcarskie sery, DM 19/21, 21/21 \\
\hline 17 & kremy orzechowe Frutta e Bacche, DM 19/21, 20/21, 21/21, G 20/21 \\
\hline 18 & produkty Casa della Piada, DM 21/21 \\
\hline 19 & ryby Sapori di mare, DM 23/21, 24/21, 25/21, 26/21 \\
\hline 20 & moka Pedrini, DM 24/21 \\
\hline 21 & akcesoria kuchenne DIVA, DM 24/21 \\
\hline 22 & wino Centine, DM 26/21 \\
\hline 23 & woda mineralna San Benedetto, DM 26/21 \\
\hline 24 & sos Biffi, DM 26/21 \\
\hline 25 & market spożywczy IPER, DM 26/21 \\
\hline 26 & szampan Dom Perignon, G 18_19/21 \\
\hline 27 & agregaty chłodnicze Frigo2000, G 18_19/21 \\
\hline
\end{tabular}

Źródło: oprac. własne

29 „Sztuka łączenia ziół”.

${ }^{30} \mathrm{Z}$ badania celowo wykluczyłam reklamy leków na jelito drażliwe oraz reklamy jedzenia dla zwierząt.

${ }^{31}$ Symbol DM oznacza tygodnik Donna Moderna, G - Grazia. Symbole numeryczne przytoczone obok nazw artykułów oznaczają numer czasopisma i rok wydania. 
Jak widać, niektóre przekazy reklamowe powtarzają się w obu tytułach, ale i w kolejnych edycjach czasopism. Lista promowanych artykułów jest różnorodna, nie można wskazać kategorii dominujących. Ponadto, ilość poszczególnych reklam tego rodzaju w badanych numerach czasopisma nie jest przytłaczająca - dominują reklamy o tematyce modowej i kosmetycznej.

O ile wspomniane powyżej reklamy pełnią w czasopismach rolę czysto perswazyjną, o tyle formami przekazu o charakterze zdecydowanie bardziej informacyjnym są dłuższe wywiady dedykowane tematyce kulinarnej. Można traktować je częściowo jako teksty edukacyjne, szerzące wiedzę na temat aktualnych trendów, informujące o tym, co się w gastronomii zmienia, ale należy zwrócić uwagę na mogące wzbudzać zastrzeżenia wspólne elementy - wszystkie wywiady przeprowadzono z Włochami lub Włoszkami i z każdego z nich wyłania się wizja kuchni włoskiej (bądź regionalnych kuchni Włoch) jako najbardziej godnej zainteresowania, a zawód chefa jest przedstawiany jako idylla ${ }^{32}$.

Tab. 2. Wywiady

\begin{tabular}{|c|l|}
\hline 1 & Benvenuti nel nostro forno ZEN (di Anna Magli), DM 9/21 \\
\hline 2 & Dalla carriera in Amazon al sogno di una fattoria etica (di Valeria Vignale), DM 15/21 \\
\hline 3 & Valentina Raffelli: la chef che non butta via niente (di Elisa Venco), DM 17/21 \\
\hline 4 & La rivoluzione dei giovani chef (di Stefania Carlevaro), DM 24/21 \\
\hline 5 & Salvo il cibo invenduto in mercati (di Chiara Sessa), DM 25/21 \\
\hline 6 & Ho rinunciato a Wall Street per cucinare nel mio Abruzzo (di Laura Pranzetti), DM 26/21 \\
\hline 7 & Grazia: Oltre la tavola. In cucina non vinco mai da solo (di Annalia Venezia), G 13/21 \\
\hline 8 & A tavola cambieremo il mondo (di Marina Speich), G 18_19/21 \\
\hline
\end{tabular}

Źródło: oprac. własne

Tekstami realizującymi funkcję impresywną, stanowiącymi kategorię pośrednią między reklamą a informacją, są wszelkiego typu porady i przepisy kulinarne, jak również krótkie przykłady opisów czynności powiązanych z jedzeniem, sugerujące czytelniczkom, jak postępować w codziennych lub nietypowych sytuacjach. Ta forma przekazu w analizowanym materiale okazała się najbardziej liczna. Poniżej tabelaryczne zestawienie poruszanych tematów:

Tab. 3. Porady

\begin{tabular}{|l|l|}
\hline 1 & Cerchi lavoro? Prendi un aperitivo, DM 9/21 \\
\hline 2 & Ti va un caffè? DM 9/21 \\
\hline 3 & L'arte di cambiare le spezie (di Manuela Soressi), DM 9/21 \\
\hline
\end{tabular}

${ }^{32}$ Bohaterowie wywiadów - taka może się nasuwać konkluzja - porzucają intratne posady na amerykańskiej giełdzie albo w liczących się korporacjach, aby kontynuować swój rozwój w branży gastronomicznej. 


\begin{tabular}{|c|c|}
\hline 4 & Przepisy kulinarne, s. 109-111, DM 9/21 \\
\hline 5 & Il the che fa bene alla pelle, DM 11/21 \\
\hline 6 & È il momento di assaggiare formaggi VEG (di Manuela Soressi), DM 11/21 \\
\hline 7 & Przepisy kulinarne, s. 103-105, DM 11/21 \\
\hline 8 & Il cibo a domicilio che non ti aspetti, DM 11/21 \\
\hline 9 & Quel tocco di acido che fa la differenza (di Nina Gigante), DM 12/21 \\
\hline 10 & Przepisy kulinarne, s. 111-114, DM 12/21 \\
\hline 11 & La lunga stagione dei carciofi (di Manuela Soressi), DM 13/21 \\
\hline 12 & Przepisy kulinarne, s. 109-111, DM 13/21 \\
\hline 13 & Przepisy kulinarne, s. 166-172, DM 15/21 \\
\hline 14 & Przepisy kulinarne, s. 106-110, DM 16/21 \\
\hline 15 & Przepisy kulinarne, s. 111-113, DM 17/21 \\
\hline 16 & Come si sceglie il pecorino (di Manuela Soressi), DM 18/21 \\
\hline 17 & Przepisy kulinarne, s. 117-120, DM 18/21 \\
\hline 18 & Przepisy kulinarne, s. 107-110, DM 19/21 \\
\hline 19 & Przepisy kulinarne, s. 116-118, DM 20/21 \\
\hline 20 & Przepisy kulinarne, s. 111-113, DM 21/21 \\
\hline 21 & Przepisy kulinarne, s. 116-118, DM 22/21 \\
\hline 22 & Facciamo ordine in cucina (di Annalisa Piersigilli), DM 23/21 \\
\hline 23 & Idee furbe per piatti da chef, DM $23 / 21$ \\
\hline 24 & Ricominciamo a mangiare pomodori (di Manuela Soressi), DM 23/21 \\
\hline 25 & Przepisy kulinarne, s. 107-110, DM 23/21 \\
\hline 26 & Crea il gusto che vuoi, DM 25/21 \\
\hline 27 & Przepisy kulinarne, s. 117-121, DM 25/21 \\
\hline 28 & Il pic nic è servito, DM $26 / 21$ \\
\hline 29 & Le virtù nascoste del pistacchio (di Nina Gigante), DM 26/21 \\
\hline 30 & Przepisy kulinarne, s. 163-166, DM 26/21 \\
\hline 31 & Cucina d'autore, G 5/21 \\
\hline 32 & Ragazzi, a tavola (rubryka Grazia Gnam), G 6/21 \\
\hline 33 & Una morbida regina (rubryka Grazia Gnam), G 8/21 \\
\hline 34 & L'eleganza di un brodo (rubryka Grazia Cucina d'autore), G 9/21 \\
\hline 35 & Intorno a un gin tonic (rubryka Grazia Gnam), G 10/21 \\
\hline 36 & Il mare d'inverno (rubryka Grazia Cucina d'autore), G 11/21 \\
\hline 37 & Unico come un risotto (rubryka Grazia Gnam), G 12/21 \\
\hline 38 & Profumo di mare (rubryka Grazia Cucina d'autore), G 13/21 \\
\hline 39 & Il gusto di non sprecare più nulla (di Massimo Bottura), G 14_15/21 \\
\hline 40 & Inventa un'altra pizza (rubryka Grazia Gnam), G 14_15/21 \\
\hline 41 & La Pasqua è un sapore a sorpresa (rubryka Grazia Cucina d'autore), G 16/21 \\
\hline 42 & A tutto il vapore (rubryka Grazia Gnam), G 17/21 \\
\hline 43 & Verdi come la primavera (rubryka Grazia Gnam), G 20/21 \\
\hline
\end{tabular}


Na tym obecność wątków kulinarnych we współczesnej włoskiej prasie kobiecej się nie kończy. Ostatnią grupę tekstów można określić roboczo mianem „inne” i zaliczyć tutaj, m.in., treści, w których są dostrzegalne cechy dyskursu diet odchudzających $^{33}$ a zatem sugestie, aby rozpocząć odchudzanie, wskazówki na temat dietetycznych dań i ich walorów, opisy składników, których należy unikać w trosce o zachowanie odpowiedniej wagi ciała. $\mathrm{W}$ tej grupie uwzględniam również teksty informacyjne o tematyce medycznej, dotyczące zaburzeń odżywania (anoreksja, bulimia) oraz reklamy preparatów wspomagających odchudzanie.

Tab. 4. Inne, w tym dyskurs diet odchudzających

\begin{tabular}{|r|l|}
\hline 1 & reklama preparatu na metabolizm, DM 9/21 \\
\hline 2 & tekst sponsorowany - herbatniki Mulino Bianco, DM 11/21 \\
\hline 3 & Le chips light, DM 12/21 \\
\hline 4 & Voglio un corpo super (di Michele Mereu), G 20/21 \\
\hline 5 & Storie: L'ideatrice del veganesimo felice, DM 15/21 \\
\hline 6 & Mangia più pasta, DM 15/21 \\
\hline 7 & Fai come gli inglesi, DM 15/21 \\
\hline 8 & Le verdure da riscoprire, DM 15/21 \\
\hline 9 & Che ne dici di ridurre al minimo gli sprechi in cucina? (di Valeria Colavecchio), DM 16/21 \\
\hline 10 & Ti va un tè? (di Annalisa Piersigilli), DM 16/21 \\
\hline 11 & Cellulite dalla A alla Z (di Claudia Bortolato), DM 16/21 \\
\hline 12 & tekst sponsorowany - czekoladki Chocoflow, DM 16/21 \\
\hline 13 & Anche noi uomini veniamo derisi per il nostro corpo (di Federico Baccomo), DM 16/21 \\
\hline 14 & Ci facciamo uno spuntino? (di Valentina Colavecchio), DM 17/21 \\
\hline 15 & E adesso la dieta arriva a domicilio (di Nina Gigante), DM 17/21 \\
\hline 16 & tekst sponsorowany - szafran 3 Cuochi, DM 18/21 \\
\hline 17 & tekst sponsorowany - Casa della piada CRM, DM 18/21 \\
\hline 18 & Una notte 20 anni fa sono diventata bulimica, DM 19/21 \\
\hline 19 & Diete \& co. Noi cresciute col mito del ventre piatto (di Geppi Cucciari), DM 19/21 \\
\hline 20 & Facciamo pace con le verdure (di Nina Gigante), DM 19/21 \\
\hline 21 & Una lettrice ci scrive: vorrei incontrare il mago della pizza, DM 20/21 \\
\hline 22 & Meno dolci e più mindfulness prima del ciclo (di Cinzia Testa), DM 20/21 \\
\hline 23 & Questo grano è proprio speciale (di Manuela Soressi), DM 20/21 \\
\hline 24 & reklama Kilocal Age Menopausa, DM 20/21, 24/21 \\
\hline 25 & La torta di verdure (di Nina Gigante), DM 21/21 \\
\hline 26 & Il vero cibo eco (di Nina Gigante), DM 21/21 \\
\hline 27 & reklama Kilocal Coresterolo, DM 21/21, 22/21, 23/21, 24/21, 26/21 \\
\hline
\end{tabular}

${ }^{33} \mathrm{~W}$ tabeli pogrubioną czcionką wyróżniono teksty stanowiące korpus zawierający elementy dyskursu diet odchudzających. 


\begin{tabular}{|l|l|}
\cline { 2 - 2 } 28 & Isa, la chef “originale”, DM 22/21 \\
\hline 29 & Mai provato la bresaola così? (di Stefania Carlevaro), DM 22/21 \\
\hline 30 & Chef Alessandro Borghese wspiera zbiórkę pieniędzy na badania naukowe, DM 24/21 \\
\hline 31 & reklama społeczna Latte nelle scuole, DM 25/21, 26/21 \\
\hline 32 & SOS lato B. (di Laura D’Orsi), DM 25/21 \\
\hline 33 & Ma cosa sono i dolci fit? (di Nina Gigante), DM 25/21 \\
\hline 34 & Kdimagryl, DM 26/21 \\
\hline 35 & Con le amiche vinceremo l'anoressia e la bulimia, G 13/21 \\
\hline 36 & Sulla tavola di Pasqua, G 14_15/21 \\
\hline
\end{tabular}

Źródło: oprac. własne

W następnej części zostaną przedstawione obserwacje poczynione $\mathrm{w}$ oparciu o kategorie terminologii retorycznej.

\subsection{Analiza retoryczna}

Dyscyplinowanie kobiecych ciał za pomocą reżimów dietetycznych zachwalanych w popularnej prasie kobiecej może się odbywać na trzech płaszczyznach.

Pierwszą strategią jest wzmacnianie wiarygodności tekstów poprzez odwołanie się do zabierających głos autorytetów ${ }^{34}$ (ethos). Jak pokazał korpus wyłoniony $\mathrm{z}$ analizowanego materiału, aktualnie oprócz dobrze znanych, należących do stałego repertuaru postaci cieszących się domniemanym szacunkiem i poważaniem ${ }^{35}$ czytelniczek, do których adresowany jest przekaz (przykłady 1-5), autorzy dołączyli i powołali symbolicznie na specjalistów nową grupę osób: szefów kuchni (przykład 6).

(1) Mangia quando hai fame. È la filosofia dell'intuitive eating che rigetta diete e restrizioni e privilegia la consapevolezza e la fiducia nei segnali del corpo. Tra le fan ci sono

Demi Lovato e Lena Dunham che va pazza per i pancakes ${ }^{36}$ (DM 17/21 "Ci facciamo uno spuntino?", s. 54).

${ }^{34}$ „O tym, co jest autorytetem, decyduje założona i wyobrażona opinio communis, czyli pewna wspólnota przekonań łącząca mówcę i słuchaczy, autora i odbiorców” (Ziomek 2000: 105).

${ }^{35}$ Zadaniem retoryki jest odnajdywanie argumentów a nie ich wynajdywanie, czyli tworzenie od zera (Ziomek 2000: 11), oznacza to korzystanie z gotowych argumentów-idei i sposobów ich wyrażania, należących do repertuaru, w jaki wyposażona jest każda wspólnota. W latach 2005-2008 włoscy autorzy tego typu tekstów powoływali się na światowe gwiazdy kina i muzyki, ekspertów z obszaru medycyny (psychiatrzy, dietetycy) a także postaci powiązane z organizacjami, których nazwy, niektóre anglojęzyczne, sugerowały związek z medycyną. Tekst w pełni innowacyjny byłby całkowicie niezrozumiały dla odbiorcy jako pozbawiony odniesień do wspólnej kultury (Ziomek 2000: 18).

${ }^{36}$,Jedz, kiedy odczuwasz głód. Na tym polega filozofia intuitive eating, odrzucająca surowe diety, stawiająca na samoświadomość i umiejętność wsłuchiwania się w sygnały, wysyłane przez ciało. Wśród zwolenniczek tej koncepcji są Demi Lovato i Lena Dunham, która oszalała na punkcie naleśników”. 
(2) La cantante Noemi si è presentata sul palco dell'ultimo Festival di Sanremo con una ritrovata forma fisica. Non a caso il suo ultimo album si intitola Metamorfosi, un gioco di parole che allude alla sua recente trasformazione e una nuova dieta ${ }^{37}$ (G 20/21 "Voglio un corpo super", s. 138).

(3) "Lo spuntino che consumi quando ti va e in autonomia mira a soddisfare i tuoi bisogni, che si tratti della ricerca di una «coccola» gustosa, di un boost di energia o di un surplus nutrizionale" spiega la nutrizionista Elisa Hopes ${ }^{38}$ (DM 17/21 "Ci facciamo uno spuntino?", s. 55).

(4) Stefano Erzegovesi, psichiatra e nutrizionista dell'Ospedale San Raffaele di Milano, non è di questa idea ${ }^{39}$ (DM 17/21 "E adesso la dieta arriva a domicilio", s. 107).

(5) Per questo nel processo si incontrano diversi professionisti: psicologo, nutrizionista, dietista, chirurgo estetico, cardiologo, endocrinologo e ortopedico ${ }^{40}$ (G 20/21 "Voglio un corpo super", s. 138).

(6) La consegna del cibo a casa è ormai una realtà affermata anche da noi e fra le proposte ci sono anche quelle pensate da team di nutrizionisti e chef ${ }^{41}$ (DM 17/21 "E adesso la dieta arriva a domicilio", s. 106).

Może to mieć związek z dużą popularnością ${ }^{42}$ i rozgłosem, jaki osoby te zyskały w ciągu ostatniego dziesięciolecia dzięki formatom telewizyjnym, których tematem jest gotowanie i rywalizacja ${ }^{43}$.

Elementy scjentyzacji, oprócz odniesień do świata medycyny, przyjmują formę powoływania się na organizacje, których nazwa sugeruje profesjonalizm, światowość i powiązania z badaniami naukowymi. Część z przywołanych podmiotów rzeczywiście niebezpodstawnie cieszy się dobrą opinią (przykład 7 - Uniwersytet Harvarda, Organizacja Narodów Zjednoczonych do spraw Wyżywienia i Rolnictwa, Światowa Organizacja Zdrowia). Natomiast równolegle z nimi na tej samej płasz-

37 „Piosenkarka Noemi pojawiła się na scenie ostatniego Festiwalu w Sanremo odmieniona pod względem formy fizycznej. To nie przypadek, że jej najnowszy album nosi tytuł Metamorfosi, gra słów nawiązująca do niedawnej transformacji i nowej diety".

38 „Przekąska, którą jesz, kiedy chcesz i która ma na celu zaspokojenie twoich potrzeb, bez względu na to czy chodzi o poszukiwanie przyjemnego „kąska”, zastrzyku energii czy nadwyżki odżywczej”, wyjaśnia dietetyk Elisa Hopes".

39 „Stefano Erzegovesi, psychiatra i dietetyk ze szpitala San Raffaele w Mediolanie, jest odmiennego zdania".

${ }^{40}$ „Z tego powodu w procesie leczenia uwzględniani są różni specjaliści: psycholog, dietetyk, chirurg plastyczny, kardiolog, endokrynolog i ortopeda".

${ }^{41}$ „Zamawianie jedzenia do domu jest już praktyką, która się u nas przyjęła, a propozycje posiłków zostały opracowane przez team dietetyków i szefów kuchni”.

${ }^{42}$ Podobnie rzecz się ma $\mathrm{z}$ instagramerkami, które pojawiają się $\mathrm{w}$ tekstach sporadycznie jako przykład głosu eksperckiego, przy czym nie muszą dysponować fachową wiedzą na temat odżywiania, aby stanowić argument w akcie perswazyjnym i realizować jego zawartość treściową.

${ }^{43}$ Np. kulinarny talent show MasterChef Italia. Pojęcie masterchefa w 2018 roku jako neologizm pojawiło się we włoskiej encyklopedii Treccani. https://www.treccani.it/enciclopedia/masterchef_\%28 altro\%29/ (dostęp: 30.06.2021). 
czyźnie w dyskursie funkcjonują podmioty mało znane, krótko istniejące, nie wiadomo przez kogo powołane oraz finansowane i jakimi kierujące się celami (przykłady 7-8):

(7) La soluzione suggerita dalla Dieta Planetaria (Planetary Health Diet), messa a punto da un team di studiosi di Harvard, FAO e OMS con l'obiettivo di dimezzare entro il 2050 i gas serra e le morti per malattie legate all'obesità, è di ribaltare il concetto che noi abbiamo del nostro piatto ${ }^{44}$ (DM 21/21 "Il vero cibo eco", s. 108).

(8) Il delivery sano, secondo l'Osservatorio The World After Lockdown, sarà uno dei protagonisti principali delle nuove abitudini alimentari ${ }^{45}$ (DM 17/21 "E adesso la dieta arriva a domicilio", s. 106).

Drugą istotną grupą mechanizmów i zabiegów perswazyjnych stanowią elementy wynikające $\mathrm{z}$ wewnętrznych, racjonalnie przedstawianych cech samej diety (logos). $\mathrm{Z}$ analizowanego dyskursu diet dowiadujemy się, że proponowane reżimy odżywiania pozwolą nam zaoszczędzić czas (przykłady 9-10), są popularne (11-12), nie wymagają wysiłku (13), a wręcz obiecują dodatkowe zalety: przyjemność z jedzenia i prozdrowotne walory posiłków (14).

(9) Risparmio tempo, non cucino e mangio il cibo già porzionato: avrò fatto la scelta giusta? ${ }^{46}$ (DM 17/21 "E adesso la dieta arriva a domicilio", s. 106).

(10) Ordini con un click ${ }^{47}$ (DM 17/21 "E adesso la dieta arriva a domicilio", s. 106).

(11) I menu seguono i principi della dieta mediterranea, $[\ldots]$, e i trend nutrizionali più in voga ${ }^{48}$ (DM 17/21 "E adesso la dieta arriva a domicilio", s. 106).

(12) Questi dolci sono l'ultimo trend della cucina salutare ${ }^{49}$ (DM 25 "Ma cosa sono i dolci fit?", s. 114).

(13) $[\ldots]$ offrono piani personalizzati, basati sul computo calorico e pensati, oltre che per dimagrimento, anche per il sostegno della massa magra. Che tu segua una dieta onnivora, vegetariana, vegana, proteica o a basso indice glicemico, non farai fatica a trovare cibi adatti a te ${ }^{50}$ (DM 17/21 "E adesso la dieta arriva a domicilio", s. 106).

${ }^{44}$ „Rozwiązanie zaproponowane przez Dietę Planetarną (Planetary Health Diet), opracowane przez team badaczy z Harwardu, Światowej Organizacji Zdrowia i ONZ ma na celu zmniejszenie o połowę do roku 2050 emisji gazów cieplarniach i zgonów spowodowanych otyłością i polega na nowym spojrzeniu na kwestie jedzenia".

${ }^{45}$ Dostawy do domu zdrowych produktów, według Obserwatorium The World After Lockdown, staną się głównym trendem naszych nowych zwyczajów żywieniowych".

${ }^{46}$ „Oszczędzam czas, nie gotuję, spożywam gotowe porcje posiłków - czy podjęłam słuszną decyzję?".

${ }^{47}$ „Zamawiasz jednym kliknięciem”.

${ }^{48}$ „Menu jest zgodne z zasadami diety śródziemnomorskiej [...] i najpopularniejszymi trendami żywieniowymi”.

49 „Te słodycze to najnowszy trend w zdrowym gotowaniu”.

${ }^{50}$, ,[...] oferują spersonalizowane plany dietetyczne, bazujące na liczeniu kalorii i przeznaczone nie tylko do odchudzania, ale także do wspomagania beztłuszczowej masy. Niezależnie od tego, czy stosu- 
(14) Ecco una torta di verdura [...], perfetta per le amiche a dieta. E la cosa bella è che oltre che super gustosa è davvero sana: ricchissima di vitamine, fibre, grassi "buoni", carboidrati complessi e persino proteine vegetali ${ }^{51}$ (DM 21/21 "La torta di verdure", s. 106).

Rzadkim, ale zasługującym na zauważenie zabiegiem jest prezentowanie diety jako jej antytezy: dieta, która nie nakłada żadnych ograniczeń, nie oczekuje żadnych wyrzeczeń a ma przynieść skutek pod postacią utraty kilogramów (przykład 15).

(15) Lei no. Non impone diete, rinunce o doveri, ma suggerisce un percorso graduale di "mentalità positiva": concentrarsi su ciò che aggiungiamo ai piatti, sugli ingredienti nuovi, più che su quanto eliminiamo, E a questo punto, tutte a provare le ricette di Carlotta (che sono anche su YouTube) ${ }^{52}$ (DM 15/21 "L'ideatrice del veganismo felice", s. 23).

Nowością, w stosunku do korpusu badanego w latach ubiegłych, jest pojawienie się w dyskursie diet odchudzających wątków ekologicznych. Dieta, według autorów tekstów, ma służyć nie tylko pojedynczym jednostkom w celu poprawy stanu zdrowia, redukcji nadmiarowych kilogramów, ale i stanowi narzędzie do walki o stan środowiska naturalnego, w jakim żyjemy (przykłady 16-18).

(16) Non è un elogio della dieta mediterranea, ma un invito a ridurre il consumo di riso. Questo cereale è infatti nella classifica dei 10 alimenti che consumano più acqua stilata dal Water Footprint Network ${ }^{53}$ (DM 15/21 "Mangia più pasta", s. 123).

(17) E non sono „costosi” nemmeno per il Pianeta: nella maggior parte dei casi, gli imballaggi sono eco e biodegradabili ${ }^{54}$ (DM 17/21 "E adesso la dieta arriva a domicilio", s. 106-107).

(18) Per aiutare il Pianeta non servono scelte estreme. Nascono le diete che non escludono la carne ma insegnano quando mangiarla e come sceglierla ${ }^{55}$ (DM 21/21 "Il vero cibo eco", s. 108).

jesz dietę wszystkożerną, wegetariańską, wegańską, białkową czy o niskim indeksie glikemicznym, nie będziesz mieć problemów ze znalezieniem produktów odpowiednich dla siebie".

${ }^{51}$ „Oto placek warzywny, [...] idealny dla przyjaciółek na diecie. A wspaniałe jest to, że oprócz tego, że jest bardzo smaczny, jest naprawdę zdrowy: pełen witamin, błonnika, „zdrowych” tłuszczów, węglowodanów złożonych, a nawet białek roślinnych".

${ }^{52}$ „Nie ona. Nie narzuca diet, wyrzeczeń czy obowiązków, ale sugeruje stopniową ścieżkę „pozytywnego nastawienia": skupienie się na tym, co dodajemy do potraw, na nowych składnikach, a nie na tym, co eliminujemy. Koniecznie sprawdźcie przepisy kulinarne Carlotty (są dostępne także na YouTube)".

${ }^{53}$ „Nie jest to pochwała diety śródziemnomorskiej, ale zaproszenie do ograniczenia spożycia ryżu. Ten produkt znajduje się w opracowanym przez Water Footprint Network rankingu 10 artykułów spożywczych, które w procesie produkcji wymagają najwięcej wody".

${ }^{54}$ „I nie są „kosztowne” dla naszej planety: w większości przypadków opakowanie jest ekologiczne i biodegradowalne". 
Jest to wyraźny znak, że w dyskursie diet odchudzających mamy do czynienia ze zjawiskiem mody językowej podążającej za zjawiskami pozajęzykowymi. Pojawiają się zbiory argumentów, toposy uzależnione od aktualnie podzielanych przez społeczeństwo wartości i ważnych społecznie tematów.

Trzecia, ostatnia grupa zjawisk językowych, jakie można wyodrębnić przy wykorzystaniu narzędzi retorycznych, odnosi się do sfery uczuć (pathos), które poprzez dyskurs usiłuje się wzbudzić w czytelniczkach. W przeszłości ${ }^{56}$ była to płaszczyzna chętnie wykorzystywana, niewymagająca od nadawcy specjalistycznej wiedzy, oferująca różnorodną gamę emocji, do których można się odwołać. Analiza korpusu z roku 2021 dowiodła, że prawdopodobnie odchodzi się od tego mechanizmu. Tylko w jednym tekście udało się potwierdzić obecność elementów usiłujących wzbudzić bezpośrednie reakcje emocjonalne. Chodzi tutaj o próbę zawstydzenia czytelniczek i poddanie ich czynnikom stresogennym, odwołanie się do negatywnych emocji i zasugerowanie braku silnej woli.

(19) Quando sei chiusa in casa e la noia ti assale, o sei stressata dall'ennesima call di lavoro, è facile che ti venga voglia di sgranocchiare qualcosa. E da qui ad aprire un pacco di patatine il passo è breve ${ }^{57}$ (DM 12/21 "Le chips light", s. 108).

Fakt, że odchodzi się od tej techniki perswazyjnej świadczy na korzyść współczesnego dyskursu diet odchudzających i może wynikać z coraz większej społecznej świadomości co do przemocy emocjonalnej, za jaką można by takie mechanizmy uznać.

\subsection{Dyskusja}

Aby dokończyć charakterystykę dyskursu diet, jaki wyłania się z włoskiej prasy kobiecej, należy odpowiedzieć na kilka pytań badawczych, jakie padły we wcześniejszych fragmentach niniejszego artykułu.

1. Nadawcy tekstów o wspomnianej tematyce często są anonimowi a to oznacza mniejszą odpowiedzialność za poruszane treści i nadawaną im formę. Od pewnego czasu teksty wpisujące się $\mathrm{w}$ nurt dyskursu diet posiadają wymienionych $\mathrm{z}$ imienia i nazwiska autorów (wśród autorek przeważają kobiety). Nie da się wykluczyć, że ten czynnik przyczynił się do zmian jakościowych i unikania technik, które wpływałyby na pogorszenie samopoczucia czytelniczek.

2. Adresatkami analizowanych tekstów są kobiety w różnym wieku, które sięgają po periodyk w poszukiwaniu rozrywki, porad, wiedzy na tematy takie jak moda,

${ }^{55}$ „Aby pomóc planecie, nie musisz podejmować radykalnych decyzji. Pojawiają się nowe diety, które nie wykluczają mięsa, ale uczą, kiedy je jeść i jak wybierać”.

${ }^{56}$ Ozimska (2019).

57 „Kiedy jesteś zamknięta w domu i dopada cię nuda lub stresuje cię kolejna rozmowa biznesowa, głód łatwiej cię dopada. A stąd do otwarcia paczki chipsów już tylko jeden krok.” 
kosmetyki, podróże, kultura, życie towarzyskie ${ }^{58}$. To kobiety, które się zmieniają, wraz z wiekiem, ale i na skutek dokonujących się przemian społecznych. Nie mamy pewności czy dieta odchudzająca jest zabiegiem, na który powinny się zdecydować. Nie wiemy, jaką wiedzą na tematy medyczne dysponują i czy są w stanie krytycznie ocenić proponowane im w prasie rozwiązania. Jeśli dyskurs diet pojawia się na łamach czasopisma, czytelniczki niejako zostają zmuszone do zetknięcia się z tym tematem, nawet, jeśli ich bezpośrednio nie dotyczy i nie stanowił powodu, dla którego sięgnęły po magazyn. Wydaje się celowym przeprowadzenie badań na temat recepcji dyskursu diet odchudzających wśród czytelniczek.

3. Badając kontekst prasowy, w jakim pojawia się dyskurs diet, trzeba zauważyć, że poruszany temat nie dominuje pośród tekstów o tematyce kulinarnej. Dotyczy to również procentowego udziału diet wśród wszystkich proponowanych w prasie kobiecej tematów.

4. Sam dyskurs diet może przyjmować różne formy: od krótkich, jak reklamy preparatów, po dłuższe teksty o tematyce społecznej, poruszające kwestie zaburzeń odżywiania albo wskazujące na nowości w tej sferze. W tekstach adresowanych do kobiet pojawiają się wątki męskie (przykłady mężczyzn borykających się z nadwagą i kompleksami), co sprawia, że dyskurs przestaje być domeną wyłącznie kobiet. Poszczególne teksty składają się z różnych, krótkich aktów perswazji, przy czym zaobserwowano mniejszy udział argumentów odwołujących się do emocji. Zazwyczaj autorzy korzystają z technik opartych na rzeczowym dowodzeniu i budowaniu wiarygodności.

5. Tekstom towarzyszą zdjęcia, które nie były przedmiotem analiz, ale można pokusić się o obserwację, że przemawiają do wyobraźni jako niewerbalny element perswazji. Zazwyczaj są to profesjonalne fotografie dopracowanych, finezyjnych dań, stanowiące zaprzeczenie wyrzeczeń, z którymi wiąże się dieta odchudzająca. Zdjęcia potraw uzupełniają również teksty o tematyce podróżniczej.

6. Analiza przykładów zaczerpniętych z tygodnika Grazia, pokazała, w jak zmiennym środowisku funkcjonujemy. Przed laty czasopismo regularnie publikowało rubrykę poświęconą odchudzaniu „Saper mangiare”, aktualnie dyskurs diet praktycznie jest w nim nieobecny.

\section{Wnioski końcowe}

Badając włoską prasę kobiecą z okresu 2005-2008, udało się ustalić bardzo liczną na jej łamach obecność przykładów dyskursu diet. Czytelniczki były wprost bombardowane tekstami poświęconymi odchudzaniu (Ozimska 2019: 276-302),

\footnotetext{
${ }^{58}$ Włoski rynek prasy oferuje kilka tytułów ${ }^{\text {magazynów }}$ poświęconych w całości dietom odchudzającym, np. miesięczniki Le Ricette Perdi Peso, Sano\&leggero, czy Dimagrire. W przypadku osób sięgających po wspomniane magazyny nie ulega wątpliwości, jaką tematyką zainteresowane są czytelniczki.
} 
temat ten gościł na kartach periodyków z dużą częstotliwością i przyjmował różne formy. Analiza korpusu pozwoliła wówczas wyekscerpować przykłady perswazji odnoszące się do emocji: opisujące towarzyszące kobietom uczucia lub usiłujące je wzbudzić w adresatkach tekstów, a zatem odpowiednik pathos. Aby osiągnąć ten efekt sugerowano czytelniczkom brak wiedzy, zawstydzano, wmawiano brak umiaru w jedzeniu, zazdrość o urodę, obsesję bycia piękną, posądzano o nadmierną troskę o zdrowie, wzbudzano poczucie winy, straszono, sugerowano bycie „cwaniarą" i korzystanie z trików, magicznych sztuczek, które miały dotyczyć zachwalanych reżimów żywieniowych.

$\mathrm{Z}$ drugiej strony, sięgano po narzędzia perswazji, które miały - według ich autorów bądź autorek - w obiektywny sposób przedstawiać walory diet, a zatem pełniły funkcję logos. Informowano o szybkości utraty wagi, szybkości przygotowania posiłków, prostoty korzystania z diety, jej popularności wśród użytkowniczek albo wręcz przeciwnie - ekskluzywności. Diety prezentowano ponadto jako środek do osiągnięcia innych, dodatkowych celów.

Ostatni element konstruowania przekazu perswazyjnego sprowadzał się do etho$s u$, rozumianego jako budowanie wiarygodności tekstu. Różnorodność technik ograniczała się w tym przypadku do stosowania argumentów z autorytetu oraz medykalizacji i scjentyzacji dyskursu, przy czym pod względem ilości, zaobserwowano podobne proporcje elementów ethosu, pathosu i logos.

$\mathrm{Z}$ analizowanego na potrzeby niniejszego artykułu materiału (I półrocze 2021) wyłonił się korpus o relatywnie innych cechach jakościowych. Doszło zatem w ciągu kilkunastu lat do istotnych zmian w wyborze toposów, jakimi posługuje się omawiany dyskurs.

Można zadać pytanie, gdzie podział się tak mocno eksploatowany kiedyś temat? Sądząc po rezultatach przeprowadzonego badania, został on zastąpiony dyskursem chirurgiczno-kosmetycznym, ekologicznym, technologicznym, „ciało-pozytywnym” bądź powiązanym z fitnessem. Jest to szczególnie widoczne w przypadku tygodnika Grazia, który w badanym okresie całkowicie odszedł od poruszania tematu diet odchudzających.

Druga kwestia, która wymaga dalszych pogłębionych analiz, to zaobserwowanie zarezerwowanej dotychczas dla kobiet tematyki diet odchudzających na równie podatnym gruncie lifestylowej prasy męskiej. Wydaje się, że dyskurs, jaki znamy $\mathrm{z}$ lat 2005-2008, w pewnym momencie - być może równolegle $\mathrm{z}$ kobiecym odpowiednikiem - w zależności od lokalnych uwarunkowań, zagościł na łamach współczesnej prasy męskiej, formatów takich jak Men's Health ${ }^{59}$, For Men Magazine, GQ Italia.

\footnotetext{
${ }^{59}$ Potwierdzenie tej hipotezy znajdujemy m.in. u Kimmela (2015: 451). „Obecnie cieszące się sukcesem nowe czasopisma dla mężczyzn, takie jak «Men's Health», zachęcają ich do postrzegania swoich ciał w taki sposób, w jaki nauczono postrzegać swoje ciała kobiety - jako trwające projekty, nad który-
} 


\section{Bibliografia}

Błajet, P. 2005. Ciało w kulturze wspótczesnej: wątki socjopedagogiczne. Olsztyn: Wydawnictwo Wyższej Szkoły Informatyki i Ekonomii Towarzystwa Wiedzy Powszechnej.

Flandrin, J.-L. 1999. "The humanization of eating behaviors". W zbiorze: Flandrin, J.-L. i M. Montanari (red.). Food: a culinary history from antiquity to the present. New York: Columbia University Press. 13-20.

Giddens, A. 2012. Nowoczesność i tożsamość. Warszawa: Wydawnictwo Naukowe PWN.

Karczewska, M. 2018. Forestierismi nella stampa femminile italiana e francese. Analisi qualitativa e quantitativa. Zielona Góra: Oficyna Wydawnicza Uniwersytetu Zielonogórskiego.

Kędzierska, B. 2015. „Media as a source of challenges for a contemporary woman”. W zbiorze: Zawisza, E. i M. Lubińska-Bogacka (red.). Kobieta w mozaice kulturowej. Rola stereotypów i kultury w kreacji kobiecości, tom 1. Kraków: Wydawnictwo «scriptum». 141-151.

Kimmel, M. 2015. Społeczeństwo genderowe. Gdańsk: Wydawnictwo Uniwersytetu Gdańskiego.

Lisowska-Magdziarz, M. 2006. Analiza tekstu w dyskursie medialnym. Kraków: Wydawnictwo Uniwersytetu Jagiellońskiego.

Mazzini, I. 1999. "Diet and medicine in the ancient world". W zbiorze: Flandrin, J.-L. i M. Montanari (red.). Food: a culinary history from antiquity to the present. New York: Columbia University Press. 141-152.

Mennell, S. 1987. "On the civilizing of appetite". Theory, Culture \& Society 4, 373-403.

Montanari, M. 1999. "Food systems and models of civilization". W zbiorze: Flandrin, J.-L. i M. Montanari (red.). Food: a culinary history from antiquity to the present. New York: Columbia University Press. 69-78.

Ozimska, J. 2019. "La persuasione nel discorso delle diete dimagranti - il caso della rivista femminile italiana Donna Moderna". Neophilologica 31. 276-302.

Płonka-Syroka, B. 2018. „Wstęp”. W zbiorze: Płonka-Syroka, B. i H. Grajeta (red.). Historia diety i kultury odżywiania, tom 1. Wrocław: Uniwersytet Medyczny im. Piastów Śląskich we Wrocławiu.

Prost, A. i G. Vincent. 2006. Historia życia prywatnego - tom 5: Od I wojny światowej do naszych czasów. Wrocław: Zakład Narodowy im. Ossolińskich.

Puto, M. 2014. „Ciało i cielesność współczesnej kobiety jako sposób kształtowania własnej tożsamości (na przykładzie współczesnej prozy włoskiej)". W zbiorze: Zawisza, E. i M. Lubińska-Bogacka (red.). Kobieta w mozaice kulturowej. Rola stereotypów i kultury w kreacji kobiecości, tom 1. Kraków: Wydawnictwo «scriptum».

Rebrovick, T. 2015. "The Politics of Diet: «Eco-dietetics», Neoliberalism, and the History of Dietetic Discourses". Political Research Quarterly 68 4. 678-689.

Rodgers, R.F. 2016. "The role of the "Healthy Weight" discourse in body image and eating concerns: An extension of sociocultural theory". Eating Behaviors 22. 194-198.

Surendra, A. 2019. Moda językowa na zapożyczenia angielskie w prasie kobiecej. Poznań: Silva Rerum.

Tokarz, M. 2002. "Argumentacja i perswazja”. Filozofia Nauki 3-4. 5-39.

Turner, B.S. 1982. "The discourse of diet". Theory, Culture \& Society 1. 23-32.

Wiśniewska, M. 2012. „Żywność, życie i turystyka w stylu «slow»”. Zarządzanie i Finanse 3, 161-173.

mi trzeba pracować. (Nakład czasopisma wzrósł z 250 tys. do $1,5 \mathrm{mln}$ w ciągu pierwszych siedmiu lat co stanowiło największy sukces wydawniczy na rynku czasopism w historii). Po części jest to zbieżne z ogólną dbałością o zdrowie i sprawność fizyczną, po części zaś chodzi o młody wygląd w społeczeństwie, które nie ceni starzenia się. Wydaje się jednak, że w jeszcze większym stopniu wiąże się to również z płcią kulturową". 
Wolf, N. 2014. Mit urody. Warszawa: Wydawnictwo Czarna Owca.

Ziomek, J. 2000. Retoryka opisowa. Wrocław: Ossolineum.

\section{Material badawczy}

Donna Moderna. 2021. Numery (łącznie 16): 9, 11, 12, 13, 15, 16, 17, 18, 19, 20, 21, 22, 23, 24, 25, 26.

Grazia. 2021. Numery (łącznie 13): 5, 6, 8, 9, 10, 11, 12, 13, 14-15, 16, 17, 18-19, 20. 
